\title{
THE IMPORTANCE OF ACADEMIC NEW VENTURES FOR SUSTAINABLE REGIONAL DEVELOPMENT
}

\author{
Aleksandar Vekic ${ }^{1}$, Vladimir Djakovic ${ }^{2 *}$, Jelena Borocki ${ }^{3}$, Wlodzimierz \\ Sroka $^{4}$, Jozsef Popp ${ }^{5}$ and Judit Olàh ${ }^{6}$ \\ 1) 2) 3) University of Novi Sad, Novi Sad, Republic of Serbia \\ 4) WSB University, Dąbrowa Górnicza, Poland and North West University, \\ South Africa \\ ${ }^{5)}$ Szent István University, Gödöllö, Hungary and North West University, \\ South Africa \\ ${ }^{6)}$ University of Debrecen, Institute of Applied Informatics and Logistics, Debrecen, \\ Hungary and North West University, South Africa
}

Please cite this article as:

Vekic, A., Djakovic, V., Borocki, J., Sroka, W., Popp, J. and Olàh, J., 2020. The Importance of Academic New Ventures for Sustainable Regional Development. Amfiteatru Economic, 22(54), pp. 533-550.

DOI: $10.24818 / \mathrm{EA} / 2020 / 54 / 533$

\section{Article History}

Received: 30 December 2019

Revised: 27 January 2020

Accepted: 10 March 2020

\begin{abstract}
Establishment of new entrepreneurial ventures have a direct influence on economic growth of the economy and society of every country. It relates especially to unemployment level and net income of the employees. Given these facts, the two aims of the paper are: 1) presentation of the Innovativeness of 14 countries of South - East Europe region and two additional countries: Poland and Hungary based on their overall ranking(s) as well as Information and Communication Technologies, ICT access and ICT use; and 2) to present development and business performance of academic start-up and spin-off companies in ICT sector which were created by the University of Novi Sad (Serbia) and which allowed it to become a sustainable University. The indicators such as total number of new ventures, number of employees, total revenue and average gross profit margin were used in order to analyse establishment, development and sustainability of academic ICT start-up and spinoff companies. The study shows that sustainable measures, particularly academic start-up and spin-off companies, have a very important role in sustainable economic growth (local, national and regional) and are a significant driver of innovation. They are of key importance for the sustainable development of the University.
\end{abstract}

Keywords: Global Innovation Index, Information and Communications Technologies, Innovation, Academic Start-up and Spin-off Companies, Sustainable Measures, Sustainable University.

JEL Classification: L26, M13, M15, O30, Q55

*Corresponding author, Vladimir Djakovic-v_djakovic@uns.ac.rs 


\section{Introduction}

Sustainable development is of the utmost importance for modern business, especially regarding employment level and net income. Entrepreneurship is multidimensional concept which has significant role on sustainable economic development, and Schumpeter (in his work) describes how the innovating entrepreneur challenges incumbent firms by introducing and using new inventions (Schumpeter, 2017). The research on new ventures has given increasing attention since the 90s. (Crespo and Aurélio, 2020). For economists, entrepreneurship is a "meta-economic" event, something that profoundly influences and indeed shapes the economy without itself being part of it, and also technology influence (Drucker, 1985). In one of recent definitions of entrepreneurship, Coulter (2001) states that entrepreneurship is a dynamic process where a person or persons use innovation through an organized process to seek opportunities where value can be created and delivered at the market. When considering the term entrepreneurship and new ventures, special attention should be paid to innovations (Abrahamson, 2019). Modern economies and companies are faced with the challenge of constant innovation in order to be sustainable and to further develop (Vekic et al., 2018). Based on Schumpeter definition of innovation, group of authors defined innovation as a process of developing and introducing a new product or some modifications brought to an existing product. (Popa et al., 2010). Innovation is the specific tool of entrepreneurs, the means by which they exploit change as an opportunity for a different business or a different service (Drucker, 1985).

The role of modern university is to integrate economic development into the university as an academic function along with teaching and research. This represents a new mission of university which can be defined as: effectively linking universities with users of knowledge and establishing the university as an important economic actor in modern society (Etzkowitz, 1998). This phenomenon has brought countless advantages including increased economic performance on the labor market, development of entrepreneurial actions and even personal growth (Roman and Parashiv, 2019). The changing role of university is important question and it is subject of debate in literature, e.g. it has been considered in the framework proposed in 2009 by the Local Economic and Employment programme of the OECD (Organisation for Economic Co-operation and Development). This framework evaluates university strategies, support infrastructures for entrepreneurship and start-ups, resource bases, and the state of entrepreneurial education and evaluation approaches (Antonella, 2009). One has to also add that sustainability of universities should become one of their main goals (Dabija et al., 2017).

The application of ICT technologies is observed in all areas of the industry, and their importance is constantly increasing. These technologies contribute significantly to the accelerated process of entrepreneurship and innovation development, especially for academic new ventures and their sustainability. Most available studies are concerned and focused on development entrepreneurial universities in developed economies. Given these facts the paper: 1) presents the Innovativeness of 14 countries of South - East Europe (SEE) region and two additional countries: Poland and Hungary based on their overall ranking(s) as well as Information and Communication Technologies and ICT access; and 2) presents development and business performance of academic start-up and spin-off companies in ICT sector which were created by the University of Novi Sad (Serbia) and its actions to become sustainable institution. The research gap presented in the article is related to the analysis of academic new ventures regarding the sustainable regional development with the special emphasis to the necessary sustainable measures. The research question is focused on the specificities of the 
sustainable measures in an university that is, the necessary preconditions for further growth and development, while analysing the place, role and importance of academic start-up and spin-off companies in ICT sector. Having in mind the above mentioned, there is a lack in the literature in the subject area. Namely, the subject of the research, that is the academic new ventures, presents a challenging and complex task, especially regarding the existing different models of creating sustainable universities and the different stages of development of every country that is in the focus of the research.

The rest of the paper is structured as follows. The second section is a literature review on entrepreneurial ventures and innovations being the result of their establishment. The next section summarises the methods used during data collection process. This section is followed by research results, their analysis and discussion. Finally, conclusions are presented, limitations and future directions of the research.

\section{Literature review}

Today, a special focus is placed on technological innovations that significantly change our reality and way of business. Since most of scientific research activities (which are sometimes as a result has technological innovations) are pursued at the universities, it is important to analyse how to improve and foster new ventures at the university to ensure its sustainable development. Special influence on the economic development is achieved through the newly created companies, most often in the form of academic start-ups and spin-offs. These companies are called "spinouts" and can be defined as "new firms which are created to exploit commercially some knowledge, technology or research results developed within a university" (Pirnay et al., 2003). Their ability to create an environment to stimulate their own growth and generate innovation significantly contributes to the progress of individual countries (especially those in development), as well as entire regions, especially to their sustainability. The activities undertaken by universities to commercialize their research, usually called "academic entrepreneurship" (Grimaldi et al., 2011). Universities are an important source of innovation and are considered as "engines of growth" in knowledge-based economies (Etzkowitz et al., 2000). In the last 20 years, the attention of universities toward to creation of academic "spinouts", so academic and student entrepreneurship has increased with huge influence to local economic development (Philpott et al., 2011). These new companies created within university are generators of new job positions, innovations and they led to structural changes in the economy and improvements of its main indicators such as: GDP, employment rate, economic growth, etc. (Plăiaş et al., 2011). It is not surprised that a lot of policy makers see spin-offs as particularly fertile innovators in an economy. That's mostly because spin-offs are also expected to perform better than other start-ups that lack the resource base spin-offs inherited from their parent companies and that are a step ahead of firms that do not receive support from a third party company (Koster, 2004). The main reason for this is basically connected with the fact that spin-off companies have a good network (good connections with other scientific research institutions, other spin-offs, other universities), more opportunities to become member of international projects pursued at the university level, and to use resources (tangible and intangible) which sometimes are not available to other companies, even if they are corporate spin-offs. Thanks to them, universities improve their sustainability and indirectly influence to the regional sustainability. 
In order to ensure sustainable development, universities strive to take advantage of the economic potential of their R\&D programmes and maximize their innovation potential through creating appropriate strategies, organizational structures and management processes that allow them to manage part of their R\&D portfolio (Bąk, 2016), with preserving their fundamental academic values and activities of research and teaching (Debackere, 2000). Entrepreneurial universities actively seek to innovate, to work out a substantial shift in organizational character, to become "stand-up" universities and to arrive at more promising posture for the future (Clark, 1998), with sustainable measures. Academic literature highlights the importance of newly developed entrepreneurial firms in transforming centrally planned economies of the South-East Europe (SEE) region, there has been limited attention given to understanding the dynamics of developing early-stage companies in ICT sector (Klonowski and Galebiowska-Tataj, 2010).

Academic start-up and spin-offs in ICT area are an important indicator of technological progress. A start-up is a human institution designed to create and deliver a new product or service under conditions of extreme uncertainty (Ries, 2014). Blank (2013) states that startup is temporary organization designed to search for a repeatable and scalable business model. Academic start-ups are strongly connected with educational and research institutions. These institutions support start-ups from their early stages with their own human resources, equipment, relevant practice and often with initial capital. Over the past few decades, universities have been receiving an increasing demand to go beyond their role of producing scientific and technological achievements to explore its knowledge potential (Cherubini-Alves et al., 2019), with the aim to produce novel commercial products and services.

Currently ICT sector has become one of the key technological infrastructures where existing technologies continue to rapidly develop and novel technologies are being constantly introduced, fostering the emergence of new entrepreneurial ventures (Kotnik and Stritar, 2015). ICT and their solutions are recognized as major drivers of economic growth, social changes, strengthening the competitiveness of the country, encouraging entrepreneurship and innovation, employment, etc. Special role of ICT sector is to provide strong support for regional development which can be defined as „the ability of a specific area or locality or even region to generate increasing income and improve local quality of life for its residents (Meyer-Stamer, 2016). The European Union creates special strategies and programs to support the development of high-tech companies and whole ICT sector. High tech start-up and spin-off companies represent important drivers of ICT sector development, which affects accelerated regional development. High tech companies are usually innovative enterprises, which can be defined as firms which report one or more innovations within the observation period (OECD, 2018a). It is a company that offers high capacity for creation, implementation and popularization of various innovations. One research shows that in 15 EU countries, more than 830000 start-up companies are operating across 20 start-up centres, employ more than 4,5 million people and generating over EUR 420 billion in revenue (Publication office of the EU, 2017).

Last available official data show main indicators for the European ICT sector in 2016. This sector generated EUR 580 billion of value added in Europe (about 3.75\% of EU GDP), and ICT services represented $92 \%$ of the total ICT sector of value added. The share of employment in the ICT sector relative to total employment was $3 \%$ in the EU, that is more than 6,6 million 
employees. ICT sector of the EU grew much faster than the rest of the economy in real terms. ICT services were approximately 10 times as large as ICT manufacturing (European Commission, 2018). The most powerful economies in the EU, such as: Germany, the United Kingdom, France, Italy and Spain, have the most developed ICT industry. The strong growth of the ICT sector is also recorded in countries of SEE, which have been taken into account in this research, together with Poland and Hungary. Most of these economies have adopted crosscutting digital strategies to support the development of ICT across all sectors. Poland and Hungary are included in this research because these countries are recognized as economies with strong ICT sector, with high fundamental principles and exceptional future growth prospects. Observed economies have also recognized the important role of the ICT sector and have adopted strategies to support its development in co-operation with the Information Technology (IT) industry (OECD, 2018b).

New companies, which are found within universities, faculties, institutes, are mostly called spin-off companies. These companies are the core of academic entrepreneurship and provide creating and managing companies by the students and employees of scientific institutions and research centers (Korpysa, 2014). Term of „spin-off companies“ can be viewed as form of knowledge and technology transfer from academic or other public research institution to the business entity (Stankiewicz, 1994), with the aim of creating and valorizing a new value on commercial market. Shane (2004) proposed the following definition "A university spin-off is a new company founded to exploit a piece of intellectual property created in an academic institution". This kind of companies implies a tool for technology transfer, with the goal to transfer University knowledge into application in society (Rasmussen, 2008). One of the major differences between start-up and spin-off companies is mode of investment for R\&D. Also, spin-off companies are always managed by university staff and technology is the property of an academic institution. Start-up companies can be established outside the academic institution, with an independent founder.

\section{Research methodology and sample}

A case study method was used in the analysis. The literature distinguishes single case studies and multiple case studies. The paper uses case analysis based on a multiple case studies. The legitimacy of this approach is confirmed, inter alia, by Flyvbjerg (2006) who states that: the case study may be central figure to scientific development via generalization as supplement or alternative to other research methods. In addition, conclusions from the case study method are considered more convincing and better proven (Yin, 2003). The choice of this method was due to several factors. First of all, innovation is a qualitative phenomenon, with blurred definition boundaries and the case study analysis allows the consideration of a given phenomenon in its bounded situation (Gummesson, 2007). As Gillham (2008) emphasizes, the premise for using case study analysis is the complexity of the studied phenomenon. Stake (1995) shares this opinion and claims that the high level of complexity of a given phenomenon and interest in its nature predestines case study as a research method applicable in a given study. There is no doubt that development and managing of academic ICT start-up and spin-off companies is a complex phenomenon. Secondly, as Bryman and Bell (2011) point out, the case study emphasizes the complexity and distinctive features of a given case (and this is also observed in the analysed study). In

Vol. $22 \cdot$ No. $54 \cdot$ May 2020 
addition, this paper focuses on analysis of innovativeness of observed countries and especially, academic start-up and spin-offs in ICT area that are regarded as an important indicator of technological progress. As Yin (2003) notes, the case study is an appropriate research strategy when the research is to determine the causes, premises, motives, factors or course of a given phenomenon, and when the researcher has little impact on the course of events. Thirdly, the case study method allows the use of a relatively wide range of information sources (Yin, 2003). And fourthly, the selection of cases has a significant impact on the results of research, so one should choose valuable cases to maximize learning opportunity) (Stake, 1995). It also means that one has to give up unrealistic cases or those that do not contribute anything to the study as soon as possible to. It should also be remembered that selected cases should be available to the researcher. One should add one more reason of choice of this method: case studies increase the likelihood of generating new theoretical concepts by juxtaposing opposites in the studied cases (Eisenhardt, 1989). In addition, case study allows to look "under the surface" of a given phenomenon, i.e. to know it deeper and interpret it more accurately. Eisenhardt (1989) indicates a case study as a method suitable for an in-depth understanding of a given case. In turn, according to Czakon (2011), the case study makes it possible to create theoretical proposals in a situation where a given phenomenon is imprecisely defined, the results of previous studies are contradictory or insufficient. And finally, case study is recommended for research on innovation (Hoholm and Araujo, 2011) and the specifics of innovation can be properly rendered only using qualitative methods (Wolfe and Gertler, 2004). In other words, the factors presented fit perfectly to the issue being discussed.

The article has two different directions: analysing the GII (Global Innovation Index, 2018), on one hand and examining the ICT start-ups and spin-offs, on the other hand. Firstly, in order to present the correct background we collected official data about GII for the SEE countries (according to UNESCO classification) and two additional countries: Poland and Hungary. The GII is an annual ranking of world countries by their capacity for, and success in innovation (Matthews and Brueggemann, 2015). These 16 countries were compared according to their overall ranking(s), taking into account the following parameters: Information and Communication Technologies, ICT access and ICT use. In order to illustrate the results of research, analytical tools were used (charts, diagrams, etc.). Secondly, we analysed ICT start-up and spin-off companies from the University of Novi Sad (second largest public university in Serbia) as a positive example of sustainable university. Having in mind the specificities of the developing countries and available data, the research sample comprises the SEE countries with special attention to the Republic of Serbia, Poland and Hungary. In that way the sound comparative analysis is enabled, while it will be possible to the determine the appropriate framework of sustainable university in contrast to the developed countries. Totally the group of 125 start-up and spin-off companies (60\% from ICT sector) according to their business activity, year of establishment, and some business parameters such as: total revenue and gross profit margin were analysed. Comparison of the complete data sample was made in relation to a separate subset which consists of companies belonging to the ICT sector according to their official business activity. The data were collected from official financial reports for each observed company, available on the website of Serbian Business Registers Agency (2019). 


\section{Results and discussion}

It is very important to understand the interdependence of ICT sector development and the level of innovation in the particular economy. For this purpose, a Global Innovation Index (GII) of SEE countries was selected, by displaying ranks and scores for observed year. The GII aims to capture the multi-dimensional facets of innovation and provide the tools that can assist in tailoring policies to promote long-term output growth, improved productivity, and job growth. It provides a key tool and a rich database of detailed metrics for economies, which in 2018 encompasses 126 economies, representing $90.8 \%$ of the world's population and 96.3\% of global GDP (Global Innovation Index, 2018). This index is the simple average of the Input and Output Sub-Indices, and Innovation Efficiency Ratio. For the purpose of this research definition of the SEE region was used, according to official data from the UNESCO web site (UNESCO, 2019).

In the research sample, a country with a highest rank according to the GII in 2018 is Malta at position 26, out of a total of 126 observed countries with a total score of 50.3, while the worst ranked country is North Macedonia positioned at 84th, with a total score of 29.9. Average score for all observed countries is 38.59. It is noticeable that EU member states are better ranked than non-EU countries (Figure no. 1). The development of ICTs significantly contributes to the innovation of a country and it can be noticed that countries with a more developed ICTs have a better overall rank on the GII list.

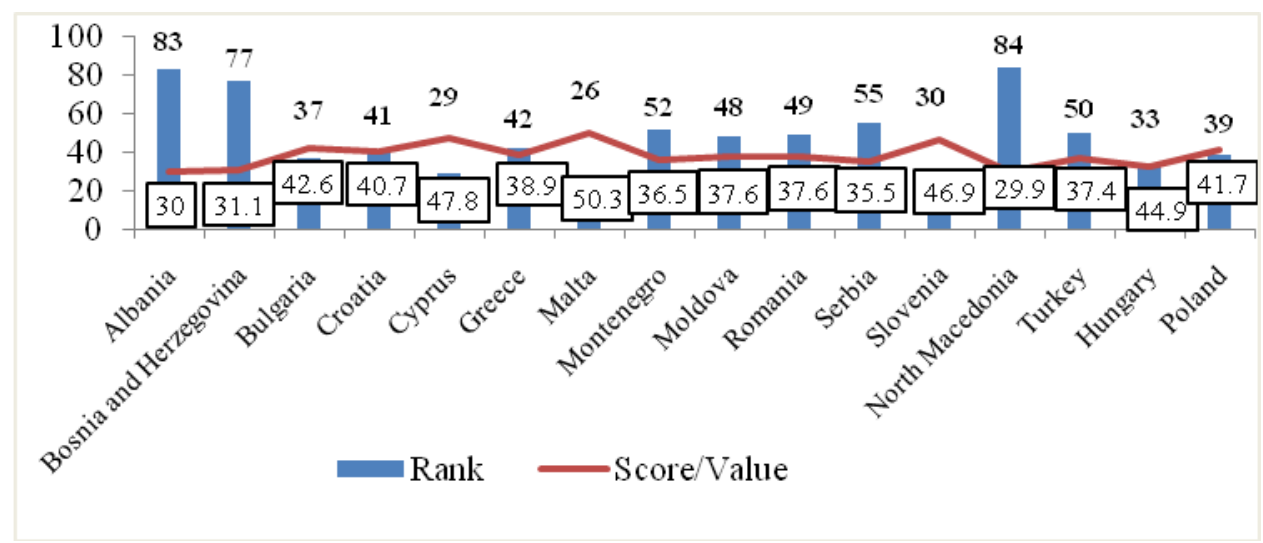

Figure no. 1: Global Innovation Index (ranks and scores) for SEE countries with Poland and Hungary in 2018

Source: Global Innovation Index, 2018

Therefore, a country with highest rank according to sub-index of ICTs in 2018 is Malta and is at position 22, out of a total of 126 observed countries, with a total score 79.87 , while the worst ranked country is Bosnia and Herzegovina at position 84, with a total score of 49.84 . Average score for all observed countries is 64.93 (Figure no. 2). 


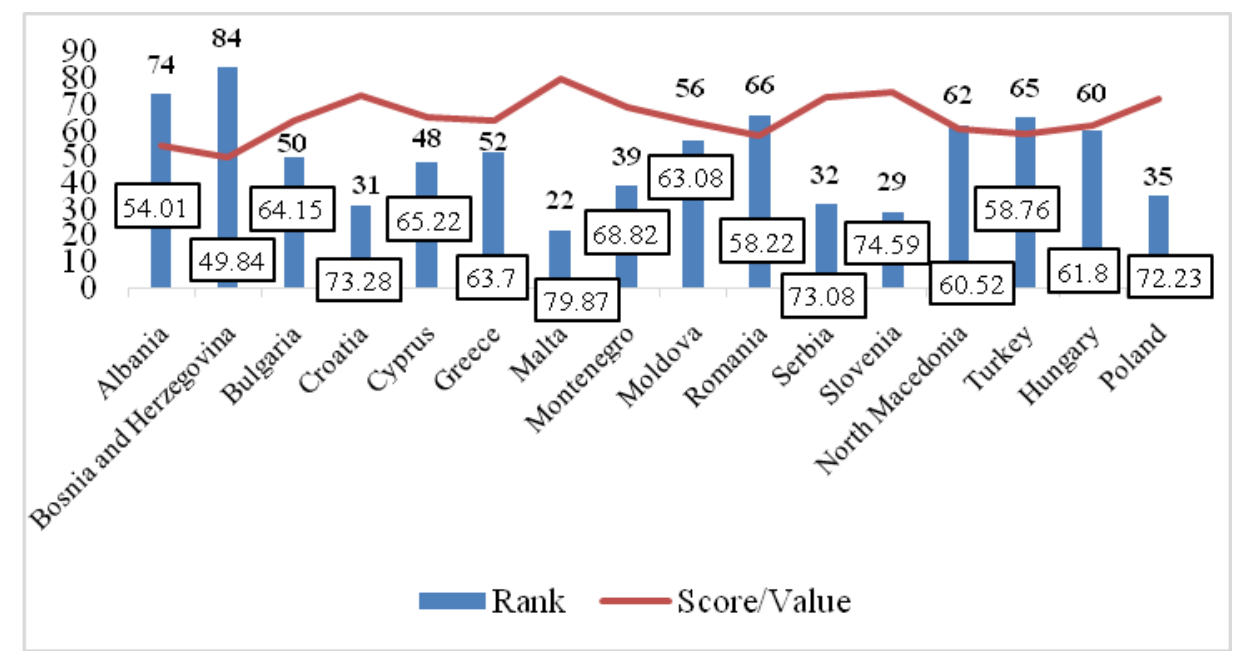

\section{Figure no. 2: Sub-pillar of ICTs (ranks and scores) as part of the pillar of Infrastructure for SEE countries with Poland and Hungary in 2018}

Source: Global Innovation Index, 2018

The third pillar of Innovation Input Sub-Index includes three sub-pillars: ICTs, General Infrastructure, and Ecological Sustainability. The ICTs sub-pillar includes four indices developed by international organizations on ICT access, ICT use, and online service by governments, and online participation of citizens (WIPO, 2016). The special focus in this research was given to ICT use and ICT access. The government of each country and local authorities are increasingly incorporating ICT policies, strategies and initiatives into their economic development strategies (Gibbs and Tanner, 1997). In this way, countries can influence on the increase use of ICTs, as well as to give a significant contribution to facilitating access to these technologies. This process requires a high level of investment and commitment in order to achieve this goal. Introduction of ICT at all education levels is very important, that help creates basis for rapid economic development. The use of ICT can enable accelerated development to take place through access to new markets, increased sustainable competitiveness, and allowed wider access to knowledge and skills, and their applying to address local conditions and individual challenges (Qureshi, 2011). Also, ICT use leads to diversification of innovation activities through various channels (Savulescu, 2015). IT strategies usually focus on the management of the IT infrastructure within a firm, with rather limited impact on driving innovations in business development (Matt et al., 2015). Innovation activity is one of the strongest grounds for the successful functioning and further enterprises development (Shpak et al., 2017). One can even state it is a driver of the country's economy (Mikiashvili and Lobzhanidze, 2017). Holders of these activities are mostly new companies in the form of: start-ups and spin-offs. Developing countries, especially from SEE are making efforts to increase the use of ICT in light to trigger the economic growth (Savulescu, 2015). Wider use and access to ICTs requires a high-quality digital access, which leads to greater opportunities for creating and finding new jobs, increasing productivity, improving revenue distribution, among others (Alderate, 2017). This requires high level of digital competence which can be defined as: specific skills, knowledge, and attitudes that make learners use 
digital media for participation, work and problem solving, independently and in collaboration with others in an innovative, critical, responsible and creative way (Hatlevik et al., 2015). In the sample of the 16 observed countries, these countries are ranked from $5^{\text {th }}-88^{\text {th }}$ position in terms of ICT access, and $28^{\text {th }}-77^{\text {th }}$ position in terms of ICT use out of 126 countries. Malta has the best score in ICT access indicator with 90.2 in total, but Cyprus has the best score in ICT use with 76.1 in total (Figure no. 3).

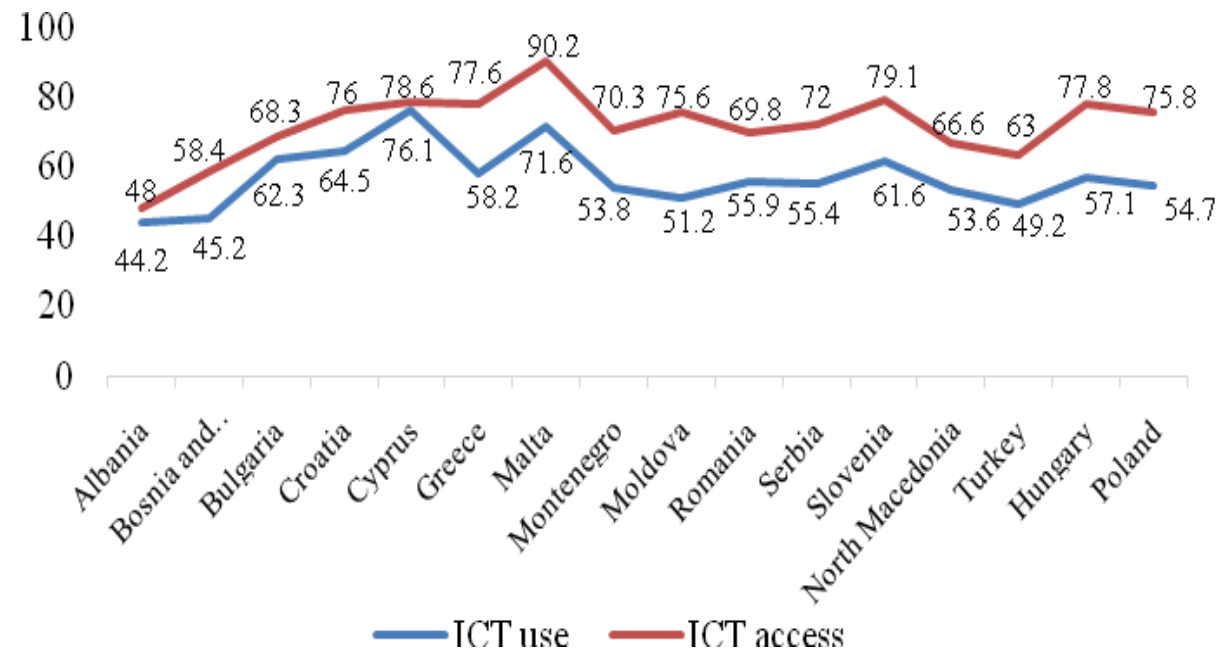

Figure no. 3: ICT use and ICT access in countries of SEE with Poland and Hungary in 2018 (scores)

Source: Global Innovation Index, 2018

Based on the collected data and the analysis made, the position of each country from the sample can be viewed according to indicators of ICT use and ICT access. The best ranked country from sample according to both indicators is Malta, with a position 28 (ICT use) and position 5 (ICT access), out of 126 countries (Figure no. 4). 


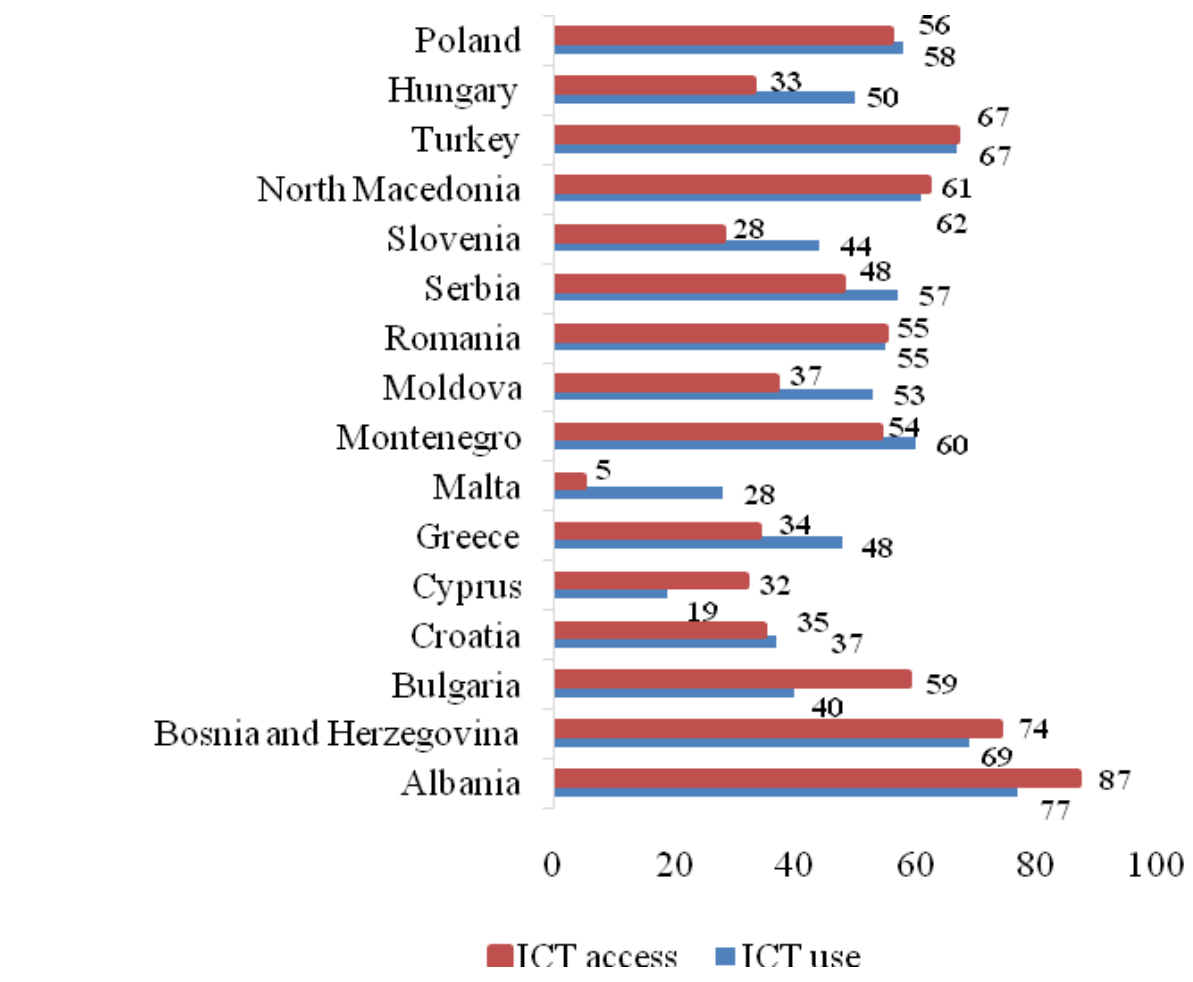

Figure no. 4: ICT use and ICT access in countries of SEE with Poland and Hungary in 2018 (ranks)

Source: Global Innovation Index, 2018

According to the observed indicators, the worst-positioned country is Albania. It can be noticed that these indicators also affect the overall ranking and scores in GII of each country.

\section{How to become a sustainable university? The case of University of Novi Sad}

The development of the ICT industry is one of the main factors in the economic growth and development of modern society, and has an important role for the future of all countries. Republic of Serbia is a country with a high growth rate of ICT use and access. Together, with government policies and support programs, this has led to the creation of a large number of companies which belong to the ICT sector. This sector is identified by the Government of Serbia as economic priority for strengthening country's competitiveness and culture oriented towards sustainability. It is the fastest growing sector in the last decade, accounting for 6 percent of country's GDP and generating international visibility for the Serbian economy (Serbia Business, 2018). The value of Serbia's ICT market in 2018 was estimated at around EUR 522.7 million, with a growth of 8\% compared to 2017 (BizLife, 2018). At GII list in 2018, Republic of Serbia is ranked with a position 57th (ICT use) and position 48th (ICT access), out of 126 countries. As in all countries from the SEE, this 
sector in Serbia is strongly export-oriented with most of the companies targeting international markets (Kleibrink, 2018). ICT sector broke a new record with exports worth EUR 1,135 billion, a growth of $26 \%$ compared to 2017, when the value of exports amounted to EUR 899 million (Serbian monitor, 2019). The data show an upward trend in terms of employment in the ICT sector. In the observed period from 2013-2017, employment in ICT sector increased 57\% (Kutlaca et al., 2018). Companies in the ICT sector pay great attention to innovation, and today in Serbia, there are more than 2700 innovative companies in this area. The development of this sector has a strong regional component, contributing significantly to value added and growth, linking and cooperating with companies all around the world.

The development of ICT sector in Serbia is directly determined by the degree of population education, also stimulating entrepreneurial activity has a huge importance. Research shows that around $84 \%$ of all current ICT employees hold a university degree (Zivkovic et al., 2018). Universities have an important role in the development and strengthening of the ICT sector have universities, they seek to stimulate entrepreneurial activity with the aim of creating academic start-up and spin-off companies. Today, these universities can be called sustainable universities which can be defined as: high education institution that combines teaching, research, and entrepreneurial activities to various degrees is a common emergent phenomenon, with profound implications for the academic role and the university's role in society (Etzkowitz, 2017). Sustainable university contributes to the regional and national social and economic development (North, 2005), and also supports the creation of new academic companies that promote competition and diversity, consequently enhancing local job growth (Guerrero et al., 2016). As a very good example, this research presents University of Novi Sad, which has a well-developed research infrastructure and great potential for innovation and sustainable development (Table no. 1).

Table no. 1: Basic indicators of University of Novi Sad

\begin{tabular}{|l|c|}
\hline \multicolumn{2}{|c|}{ University of Novi Sad - Review } \\
\hline Number of Faculties & 14 \\
\hline Number of Accredited Study Programs & around 400 \\
\hline Number of Students & more than 50.000 \\
\hline Number of Employees & more than 5.000 \\
\hline Number of Scientific Institutes & 17 \\
\hline Number of University Centers & 250 \\
\hline Number of Scientific Laboratories & 126 \\
\hline Number of Projects (up to 2016) & 127 \\
\hline Number of Partner and Coordinating International Projects & 3 \\
\hline
\end{tabular}

Source: University of Novi Sad, 2019

At the University of Novi Sad, 140 start-up and spin-off companies have been founded in 25-year period, mainly in the ICT sector (more than $60 \%$ of all founded companies), employing young engineers who graduated from the University of Novi Sad. Some of these companies implement projects for large international corporations and have contributed to Novi Sad becoming recognized internationally as a "Software Valley" (University of Novi Sad, 2019). 
The largest number of academic ICT start-up and spin-off companies (17) was established in 2012, while a small number of them was established at the beginning of the observed period (Figure no. 5). The chart shows the periods of low entrepreneurial activity in 1990s, caused by very poor economic environment, economic crisis and lack of market economy as well as the consequences of wars and period of sanctions. Research shows that rate of survived companies on the market in observed sample is high and amounts to over $60 \%$. The founders of these start-up and spin-off companies in general are members of academic staff (professors and assistants), graduates and students (University does not own these companies). Due to the establishment of entrepreneurial culture, the number of companies owned by students is constantly increasing. These companies mainly operate in the segment of: software development, computer programming, gaming industry, R\&D, consulting and other activities.

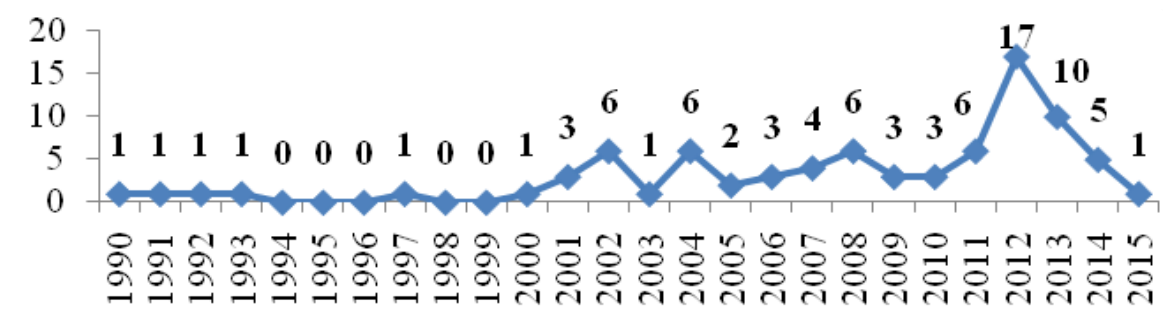

Figure no. 5: The number of founded academic ICT start-up and spin-off companies in the period 1990-2015 at the University of Novi Sad

\section{Source: University of Novi Sad, 2019}

The total increase in the number of employees in the academic ICT start-up and spin-off companies of the University of Novi Sad in the observed period is $43.55 \%$ (Figure no. 6). In region of Novi Sad operate more than 400 ICT companies, with more than 4000 employees, so almost third of all ICT companies are academic start-ups and spin-offs. Due to the accelerated development of this industry, there is currently a shortage of enough skilled workforce (more than 10,000 people), and an increase in enrolment quotas for students in the ICT fields is required. The problem is in the limited work space available to the university, as well as the lack of professional teaching staff.

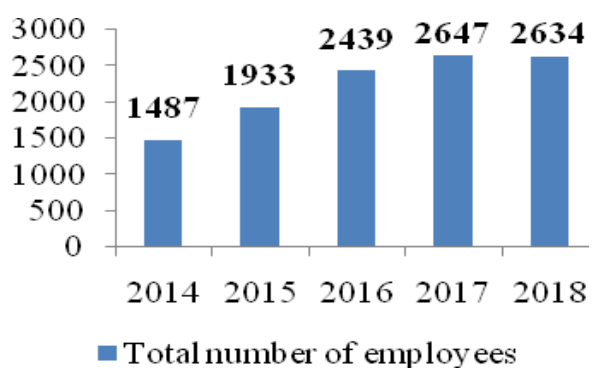

Figure no. 6: Total number of employees in academic ICT start-up and spin-off companies in period 2014-2018

Source: own elaboration based on Serbian Business Registers Agency, 2019 
Figure no. 7 shows that increase of total revenue is $59.19 \%$. The highest growth was recorded in period 2016-2017. Research shows that growth of Serbian ICT industry is twice as high compared with average growth of ICT industry in the EU. Also, export of ICT products and services twice as higher than import.

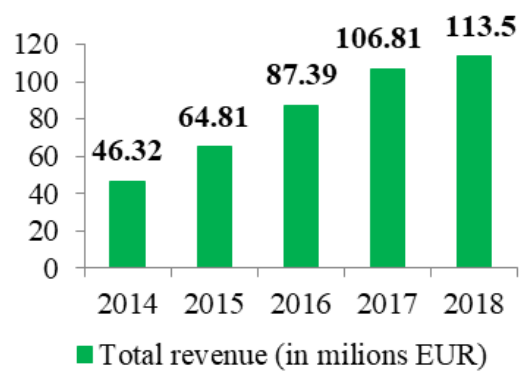

Figure no. 7: Total revenue of academic ICT start-up and spin-off companies in period 2014-2018

Source: own elaboration based on Serbian Business Registers Agency, 2019

Figure no. 8 shows average gross profit margin for observed active academic ICT start-up and spin-off companies of the University of Novi Sad. During this observed period, this business indicator has not changed significantly. The highest average gross profit margin was recorded in 2015.

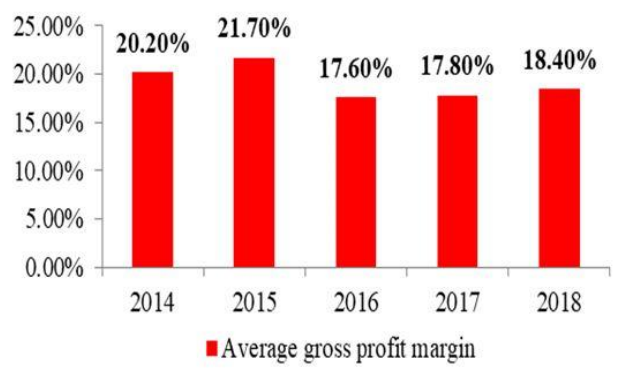

Figure no. 8: The average gross profit margin of academic ICT start-up and spin-off companies in period 2014-2018

Source: own elaboration based on Serbian Business Registers Agency, 2019

These findings show that the University of Novi Sad is one of the main generators of entrepreneurial activity in the local community, as well as the whole region, being a very good example of the sustainable organization. It has a significant role in the process of generation, attraction, and retention of talented human capital and entrepreneurs, especially in establishing new companies. The contributions of the University are also reflected in regional aspects, such as: decrease in immigration, university - industry cooperation, regional income, labor force mobility, also in improving quality of life, sustainability, etc. In the case of the University of Novi Sad the significant influence on local income and employment increase is clearly visible. It is important to emphasize the active participation of the University in the defining and implementing of local and regional development strategies. 


\section{Conclusions}

In line with modern trends, universities become more entrepreneurial, in order to create new ways for research commercialization and sustainability. By establishing a systematic mechanism for stimulating entrepreneurship and innovation, these educational institutions become the cradle of new companies' development and important drivers of local socioeconomic and regional development. A similar situation exists in the countries which are shown in this paper. In the case of the University of Novi Sad, its strong impact on local and regional economic growth is evident. Within this academic institution, a large number of start-up and spin-off companies were established, especially in the ICT sector, which becomes the most attractive sector of the Serbian economy in recent years. Even more important is that all these activities allowed it to become a sustainable University.

There are several theoretical implications of the research conducted. First of all, it constitutes the next work on academic ICT start-up and spin-off companies (which is relatively rare topic, especially in relation to the Universities). In addition, one should remember that this type of research is not conducted before, especially in terms of selected parameters which are calculated based on data from public financial reports. Therefore, SEE countries are also compared by Global Innovation Index because that is reasonable criteria. The findings of this study can be relevant to practice as it gives some recommendations to the governments and policymakers on how to increase the creation of new ventures (one may extend this group to the managers in relation to the management of the spin-off companies). This for sure would be very beneficial to the local economic development. Secondly, the detailed data collected in the analysis may be useful to formulate research hypothesis to be analysed on bigger samples. Managerial implications of the research comprises the information necessary for the creation of sound framework for formulating, implementing and evaluating of the sustainable measures in order to establish sustainable university.

Limitations of the research are the following: Firstly, this study uses a case study analysis based on one University only (data on academic start-up and spin-off companies in the Republic of Serbia can be officially found only for the University of Novi Sad; there is no obligation to keep records of these companies by universities) so it is not obvious whether the data obtained may be applied to companies operating in other sectors. Secondly, the survey takes into account some of the key business activity indicators, therefore further research can be extended by introducing new parameters for more extensive analysis. Despite these limitations the research presents a real shape of the ICT sector in the countries analysed and especially, University of Novi Sad, whose actions taken allowed it to become a sustainable University.

Future research perspectives understand the continues monitoring of academic start-up and spin-off companies performances in the dynamic business environment, while focusing on the innovation activities and their importance for the sustainable development of the university. Thus, future research implies the extension of an existing sample of the research (a larger number of companies, universities, countries, etc.) for more extensive analysis. This would significantly contribute in the determination process of the impact of academic start-up and spin-off companies on regional development, as well as creating the basis for the development of modern start-up ecosystems. Furthermore, it seems that some form of cyclical research, for example, if conducted every five to 10 years, would allow researchers 
to obtain more valid data and provide some indications as to the direction in which the sustainable development of the analysed University will evolve.

\section{References}

Abrahamsson, J., Vanyushyn, V. and Boter, H., 2019. Organisational innovativeness of international new ventures: evidence from Swedish firms. European Journal of International Management, 14(1), pp.479-495.

Alderate, M.V., 2017. Examining the ICT access effect on socioeconomic development: the moderating role of ICT use and skills. Information Technology for Development, 23(1), pp.42-58.

Agriculture and Innovation, 2019. What is innovation? [online] Available at: <https://ec.europa.eu/eip/agriculture/en/what-innovation> [Accessed 13 May 2019].

Antonella, N. ed., 2009. Local Economic and Employment Development (LEED) The Changing Boundaries of Social Enterprises. S.l: OECD Publishing.

Bąk, K., 2016. Academic entrepreneurship - conceptual framework and example from Poland. Forum Scientiae Oeconomia, 4(3), pp.105-114.

BIZlife, 2018. IT market in Serbia grew by eight percent in 2018. [online] Available at: $<$ https://www.bizlife.rs/en/business/business-news/it-market-in-serbia-grew-by-eightpercent-in-2018/> [Accessed 22 May 2019].

Blank, S., 2013. Why the Lean Start-Up Changes Everything? Harvard Business Review. [online] Available at: <https://hbr.org/2013/05/why-the-lean-start-up-changeseverything $>$ [Accessed 25 May 2019].

Bryman, A. and Bell, E., 2011. Business Research Methods. Oxford: Oxford University Press.

Alves, A.C, Fischer, B., Schaeffer, P.R. and Queiroz, S., 2019. Determinants of student entrepreneurship: An assessment on higher education institutions in Brazil. Innovation \& Management Review, 16(2), pp.96-117.

Coulter, M., 2001. Entrepreneurship in Action. Upper Saddle River: Prentice-Hall.

Clark, B. R., 1998. Creating entrepreneurial universities: Organizational pathways of transformation. Issues in higher education. Elsevier Science Regional Sales, pp.3-4.

Crespo, N.F. and Aurélio, D., 2020. Between domestic and international new ventures: the relevance of entrepreneurs' and firms' characteristics. European Journal of International Management, 14(1), pp.28-54.

Czakon, W., 2011. Zastosowanie studiów przypadków w badaniach nauk o zarządzaniu. In: W. Czakon ed., 2011. Podstawy metodologii badań w naukach o zarzadzaniu. Warszawa: Oficyna a Wolters Kluwer business.

Dabija, D.C., Postelnicu, C., Dinu, V. and Mihăilă, A., 2017. Stakeholders' perception of sustainability orientation within a major Romanian University. International Journal of Sustainability in Higher Education, 18(4), pp.533-553.

Debackere, K., 2000. Managing academic R\&D as a business at K.U. Leuven: context, structure and process. $R \& D$ Management, 30(4), pp.323-328.

Drucker, P.F., 1985. Innovation and entrepreneurship: practice and principles. San Francisco: Harper and Row Publisher Inc.

Eisenhardt, K.M., 1989. Building theories from case study research. The Academy of Management Review,14(4), pp.532-550.

Etzkowitz, H., Webster, A. and Healey, P. eds., 1998. Capitalizing knowledge: New intersections of industry and academia. S.1: Suny Press. 
Etzkowitz, H., Webster, A., Gebhardt, C. and Terra, B. R. C., 2000. The future of the university and the university of the future: evolution of ivory tower to entrepreneurial paradigm. Research Policy, 29(2), pp.313-330.

Etzkowitz, H., 2017. The entrepreneurial university. Encyclopedia of International Higher Education Systems and Institutions, pp.1-5.

Flyvbjerg, B., 2006. Five misunderstandings about case-study research. Qualitative Inquiry [e-journal] 12(2), pp.219-245. DOI: 10.1177/1077800405284363.

Gibbs, D. and Tanner, K., 1997. Information and communication technologies and local economic development policies: the British case. Regional Studies, 31(8), pp.765-774.

Gillham, B., 2008. Case study research methods. London: Continuum.

Global Innovation Index, 2018. About the global innovation index. [online] Available at: <https://www.globalinnovationindex.org/about-gii > [Accessed 3 May 2019].

Grimaldi, R., Kenney, M., Siegel, D. S. and Wright, M., 2011. 30 years after Bayh-Dole: Reassessing academic entrepreneurship. Research Policy, 40(8), pp.1045-1057.

Gummesson, E., 2007. Case study research and network theory: birds of a feather. Qualitative Research in Organizations and Management: An International Journal, 2(3), pp.226-248.

Guerrero, M., Urbano, D. and Fayolle, A., 2016. Entrepreneurial activity and regional competitiveness: evidence from European entrepreneurial universities. The Journal of Technology Transfer, 41(1), pp.105-131.

Hatlevik, O. E., Guðmundsdóttir, G. B. and Loi, M., 2015. Digital diversity among upper secondary students: a multilevel analysis of the relationship between cultural capital, self-efficacy, strategic use of information and digital competence. Computers \& Education, 81, pp.345-353.

Hoholm, T. and Araujo, L., 2011. Studying innovation processes in real-time: The promises and challenges of ethnography. Industrial Marketing Management, 40(6), pp.933-939.

International Monetary Fund, 2019. Gross Domestic Product (GDP). [online] Available at: <https://www.imf.org/external/datamapper/datasets/WEO/1> [Accessed 10 May 2019].

Kleibrink, A., Radovanovic, N., Kroll, H., Horvat, D., Kutlaca, D. and Zivkovic, L., 2018. The Potential of ICT in Serbia: An Emerging Industry in the European Context. Luxembourg: Publications Office of the European Union.

Klonowski, D. and Gołębiowska-Tataj, D., 2010. Challenges and opportunities in developing a high- tech business in Central and Eastern Europe. International Journal of Emerging Markets, 5(2), pp.138-152.

Korpysa, J., 2014. Schumpeterian Entrepreneurship in Academic Spin-off Companies in Poland. Transformations in Business and Economics, 13(3,33), pp.42-59.

Koster, S., 2004. Spin-off firms and individual start-ups. Are they really different?. In: ERSA, 44th ERSA conference. Porto, Portugal, 25-29 August 2004.

Kotnik, P. and Stritar, R., 2015. ICT as the Facilitator of Entrepreneurial Activity: An Empirical Investigation. Amfiteatru Economic, 17(38), pp.277-290.

Kutlaca, D., Zivkovic, L., Strbac, D., Semencenko, D. and Popovic-Pantic, S., 2018. ICT Case Study in Serbia: Report on the innovation potential of the software industry in Serbia. Belgrade: Institut Mihajlo Pupin, Science and Technology Policy Research Centre.

Matt, C., Hess, T. and Benlian, A., 2015. Digital transformations strategies. Business \& Information System Engineering, 57(5), pp.339-343. 
Matthews, C. H and Brueggemann, R., 2015. Innovation and Entrepreneurship: A Competency Framework. London and New York: Routledge.

Meyer-Stamer, J., 2016. Systematic Competitiveness and Local Economic Development. In: S. Bodhanya ed., 2008. Large Scale Systemic Change: Theories, Modelling and Practices. New York, NY: Nova Science Publishers.

Mikiashvili, N. and Lobzhanidze, N., 2017. Green innovations and economic policy in small economies. Forum Scientiae Oeconomia, 5(2), pp.29-40.

North, D. C., 2005. Understanding the process of economic change. S.1: Princeton University Press.

OECD, 2018a. Guidelines for Collecting, Reporting and Using Data on Innovation. 4th Edition, [online] Available at: <https://www.oecd.org/science/oslo-manual-20189789264304604-en.html> [Accessed 14 May 2019].

OECD, 2018b. Digital society in South East Europe, in Competitiveness in South East Europe: A Policy Outlook 2018. [online] Paris: OECD Publishing. Available at <https://doi.org/10.1787/9789264298576-15-en> [Accessed 25 May 2019)].

Philpott, K., Dooley, L., O'Reilly, C. and Lupton, G., 2011. The entrepreneurial university: Examining the underlying academic tensions. Technovation, 31(4), pp.161-170.

Pirnay, F., Surlemont, B. and Nlemvo, F., 2003. Toward a typology of university spin-offs. Small Business Economics, 21(4), pp.355-369.

Plăiaș, I., Pop, C.M., Băbuţ, R., Dabija, D.C., 2011. Employers’ perception of competences acquired through academic marketing training in knowledge based economy. Amfiteatru Economic, 13(30), pp.448-463.

Popa, L.I., Preda, G. and Boldea, M., 2010. Theoretical approach of the concept of innovation. Managerial Challenges of the Contemporary Society Proceedings, p.151.

Publication Office of the EU, 2017. Dynamic mapping of web entrepreneurs and startups ecosystem project. [pdf] Available at: <https://publications.europa.eu/en/publicationdetail/-/publication/638333a0-9f42-11e7-b92d-01aa75ed71a1/language-en/formatPDF/source-40842152> [Accessed 16 May 2019].

Qureshi, S., 2011. Globalization in development: Do information and communication technologies really matter. Information Technology for Development, 17(4), pp.249-252.

Rasmussen, E., 2008. Spin-off venture creation in a university context. An entrepreneurial process view. S.1: Bodø Graduate School of Business.

Ries, E., 2014. Lean startup. Belgrade: Mate.

Roman, M. and Paraschiv, D.M., 2019. The Young Entrepreneurs of Europe and the Role of International Mobility. Amfiteatru Economic [e-journal] 21(Special No. 13), pp. 763-777. DOI: 10.24818/EA/2019/S13/763

Savulescu, C., 2015. Dynamic of ICT development in EU. Procedia Economics and Finance, 23, pp.513-520.

Serbia Business, 2018. IT Sector. [online] Available at: <https://serbia-business.eu/itsector/> [Accessed 20 May 2019].

Serbian Business Registers Agency, 2019. Financial Statements. [online] Available at: <https://www.apr.gov.rs/registers/financial-statements.1698.html> [Accessed 23 May 2019].

Serbian monitor, 2019. Serbia generates over 1 bln euro in ICT exports for the first time ever. [online] Available at: <https://www.serbianmonitor.com/en/serbia-generatesover-1-bln-euro-in-ict-exports-for-the-first-time-ever/> [Accessed 23 May 2019]. 
Schumpeter, J.A., 2017. The theory of economic development. London and New York: Routledge, Taylor and Francis Group.

Shane, S., 2004. Academic entrepreneurship - University spinoffs and wealth creation. In: S. Venkataraman ed., 2004. New horizons in entrepreneurship. Cheltenham: Edward Elgar Publishing, pp.353.

Shpak, N., Satalkina, L., Sroka, W. and Hittmar, S., 2017. The social direction of enterprises' innovation activity. Polish Journal of Management Studies, 16(1), pp.187201.

Stankiewicz, R., 1994. Spin-off companies from universities. SCI Public Policy, 21(2), pp.99-107.

Stake, R.E., 1995. The art of case study research. SAGE: Oaks Thousand.

Statistical Office of the Republic of Serbia, 2019. Employment. [online] Available at: <http://www.stat.gov.rs/en-us/oblasti/trziste-rada/registrovana-zaposlenost/> [Accessed 20 May 2019].

Zivkovic, L, Kutlaca, D., Kleibrink, A. and Strbac, D., 2018. Characteristics of the software industry in Serbia. Ekonomika preduzeca, 66(3-4), pp.226-236.

UNESCO, 2019. Country Files for: South-East Europe. [online] Available at: $<$ http://www.unesco.org/new/en/venice/about-this-office/where-we-work/southeasteurope/> [Accessed 23 April 2019].

University of Novi Sad, 2019. About University. [online] Available at: <http://www.uns.ac.rs/index.php/en/university/o-univerzitetu-e/information> [Accessed 27 May 2019].

University of Novi Sad, 2019. Start-up and Spin-off companies. [online] Available at: <http://www.uns.ac.rs/index.php/en/start-up-spin-off> [Accessed 15 April 2019].

Vekic, A., Borocki, J. and Fajsi, A., 2018. Importance of innovations in business ecosystem. Novi Sad: International Scientific and Expert Conference (TEAM).

WIPPO, 2016. The Global Innovation Index (GII) Conceptual Framework. [pdf] Available at: <https://www.wipo.int/edocs/pubdocs/en/wipo_pub_gii_2016-annex1.pdf> [Accessed 5 June 2019].

Wolfe, D.A. and Gertler, M.S., 2004. Clusters from the inside and out: local dynamics and global linkages. Urban Studies [e-journal] 41(5-6), pp.1071-1093. DOI: 10.1080/00420980410001675832.

Yin, R.K., 2003. Applications of case study research. Thousand Oaks: SAGE Publications. 